\title{
Minimizing Makespan in Flow Shop Scheduling Using a Network Approach
}

\author{
Amin Sahraeian \\ Department of Industrial Engineering, \\ Payame Noor University, Asaluyeh, \\ Iran
}

\section{Introduction}

Production systems can be divided into three main categories, job shop, flow shop and fixed site. Cellular technology and flexible manufacturing system are the subsystems of job shop. Production scheduling for fixed site are categorized under the title of project planning, so we can conclude that the production scheduling in general are three forms: a) job shop production scheduling b) flow shop production scheduling and c) project production scheduling. In the traditional flow shop scheduling problem, it is assumed that there is only one machine at each stage to execute passing jobs. With the development of hardware, software, and theory in parallel computing, the traditional model of flow shop scheduling is becoming somewhat unrealistic. Defined to capture the essence of parallel computing is the so-called hybrid flow shop model, in which each job has to go through multiple stages with parallel machines instead of a single machine (Havill \& Mao, 2002). Scheduling is one of the most important decisions in production control systems. Every production system should have a kind of production scheduling, no matter whether it is managed and organized traditionally or have a systematic and scientific approach to the planning in the production system. If a scientific approach to production planning is organized, we can be sure that a better usage of the resources especially the machinery and the manpower are considered and a better situation for competition are formed in the market. In this chapter we try to use a mathematical optimization model for doing this job. The systems which we are concerned with are two subsystems of the flow shop, which are simple flow shop and hybrid flow shop. The goal is to minimize the total completion time of all the activities and the approach which are used is a linear programming which dominates the heuristic models which mostly used for the NP-Hard problems. to do this, first of all we convert the production system into the network form, then we find the critical activities which affects the total completion time (makespan), then we assign some budget to the activities to crash them, by assigning some budget to some of the operations, (Hojjati \& Sahraeyan, 2009) the operation time of these activities reduces and affects the total completion time of all the operations and because of the shortage of the budget, the problem is solved and determines which activities are better to absorb the limited budget to minimize the makespan. 


\subsection{Definition of production systems}

\subsubsection{Project production system}

A type of non-continuous systems, in which the final goods are completed in a fixed place and the machinery and manpower are moved toward the finished goods. For planning the production in this situation we use a project program like CPM(Critical Path Method), PERT(Program Evaluation and Review Technique) or GERT(Graphical Evaluation \& Review Technique). The most characteristic of this system is that, either the movement of the product is impossible (like bridges and roads and ...) or it is very difficult (like aircrafts and large ships).

\subsubsection{Job shop production system}

A job shop is a type of manufacturing process structure where small batches of a variety of custom products are made. In the job shop process flow, most of the products produced require a unique set-up and sequencing of processing steps. Similar equipment or functions are grouped together, such as all drill presses in one area and grinding machines in another in a process layout. The layout is designed to minimize material handling, cost, and work in process inventories. Job shops use general purpose equipment rather than specialty, dedicated product-specific equipment. Digital numerically controlled equipment is often used to give job shops the flexibility to change set-ups on the various machines very quickly. Job shops compete on quality, speed of product delivery, customization, and new product introduction, but are unlikely to compete on price as few scale economies exist.

When an order arrives in the job shop, the part being worked on travels throughout the various areas according to a sequence of operations. Not all jobs will use every machine in the plant. Jobs often travel in a jumbled routing and may return to the same machine for processing several times. This type of layout is also seen in services like department stores or hospitals, where areas are dedicated to one particular product or one type of service.

A job is characterized by its route, its processing requirements, and its priority. In a job shop the mix of products is a key issue in deciding how and when to schedule jobs. Jobs may not be completed based on their arrival pattern in order to minimize costly machine set-ups and change-overs. Work may also be scheduled based on the shortest processing time.

Capacity is difficult to measure in the job shop and depends on lot sizes, the complexity of jobs, the mix of jobs already scheduled, the ability to schedule work well, the number of machines and their condition, the quantity and quality of labor input, and any process improvements.

\subsubsection{Group technology and flexible manufacturing systems}

Group technology and flexible manufacturing system are the subsystems of job shop. In cellular group technology, in which the layout is cellular, factory will be broken to units called cells. In these units family parts based on its characteristics, such as parts of geometry, size or similar process are formed. And machinery that have the task of processing on the parts to be allocated cells. Machinery mentioned as possible located close to each other and machinery group is formed. Cellular production is the combination of the two job shop and project production systems. In other words, cellular system has advantages of job shop 
(production flexibility and diversity of parts) and continuous production (high rate of production) together. Cellular system is one of the most important tools to achieve the lean production.

A flexible manufacturing system (FMS) is a manufacturing system in which there is some amount of flexibility that allows the system to react in the case of changes, whether predicted or unpredicted. This flexibility is generally considered to fall into two categories, which both contain numerous subcategories. The first category, machine flexibility, covers the system's ability to be changed to produce new product types, and ability to change the order of operations executed on a part. The second category is called routing flexibility, which consists of the ability to use multiple machines to perform the same operation on a part, as well as the system's ability to absorb large-scale changes, such as in volume, capacity, or capability.

Most flexible manufacturing systems consist of three main characteristics. The work machines which are often automated $\mathrm{CNC}$ (Computer Numerically Controlled) machines are connected by a material handling system which is called AGV (Automated Guided Vehicle ) to optimize parts flow and the central control computer which controls material movements and machine flow.

The main advantage of an FMS is its high flexibility in managing manufacturing resources like time and effort in order to manufacture a new product. The best application of an FMS is found in the production of small sets of products like those from a mass production. The other advantages are Faster, Lower- cost/unit, greater labor productivity, greater machine efficiency, improved quality, increased system reliability, reduced parts inventories, adaptability to CAD/CAM(Computer-aided Design/Computer-aided Manufacturing) operations, shorter lead times.

\subsubsection{Flow shop production system}

Flow shop production system in turn is divided to three main categories: a) simple flow shop, b) hybrid flow shop and c) parallel flow shop. The simple and hybrid flow shop are studied in this chapter and the methodology for parallel flow shop is suggested for further research.

\subsubsection{Simple flow shop}

Much research works both in academic and practical fields have studied flow shop scheduling. In a flow shop system all jobs are processed on machines in the same sequence. However, the processing time of each operation might vary. All jobs are assumed to be ready to be processed at time zero. It is further assumed that there is sufficient physical buffer space between two successive machines without being concerned about the busy or idle status of that machine. A general objective is to develop a schedule that minimizes the makespan. The general flow shop scheduling problem is a NP-Complete problem and a non polynomial time algorithm is expected for these type of problems (French, 1982). The development of heuristic algorithms guarantees good solutions, (Campbel et al., 1970) especially for large size problems. In simple flow shop system there are a set of $\mathrm{m}$ machines (processors) and a set of $n$ jobs. Each job comprises a set of $m$ operations which must be 
done on different machines. All jobs have the same processing operation order when passing through the machines. There are no precedence constraints among operations of different jobs. Usually some assumptions are considered when the theoretical approach is considered. For example operations cannot be interrupted and each machine can process only one operation at a time. These assumptions are considered more deeply in the future. The problem is to find the job sequences on the machines which minimize the makespan, (Khodadadi, 2011) i.e. the maximum of the completion times of all operations (Seda, 2007). As the objective function, mean flow time, completion time variance (Gowrishankar, 2001) and total tardiness can also be used (Pan et al., 2002). The flow shop scheduling problem is usually solved by approximation or heuristic methods. Successful heuristic methods include approaches based on simulated annealing, tabu search, and genetic algorithms (Al-Dulaimi \& A.Ali, 2008).

\subsubsection{Hybrid flow shop}

Hybrid flow shop scheduling problems are quite common, especially in the process industry where multiple servers (machines) are available at each stage (Brah \& Hunsucker, 1991) as well as in certain flexible manufacturing environments (Zijm \& Nelissen, 1990). It is an extension of two classical scheduling problems, the classical flow shop and identical parallel-machine problems. Further, when processing times at a given stage dominate those at other stages, it is natural to increase the system capacity by adding another machine at this stage. A Hybrid Flow Shop (HFS) consists of a series of production stages. Each stage has several machines operating in parallel. Some stages may have only one machine, but at least one stage must have multiple machines. The flow of jobs through the shop is unidirectional. Each job is processed by one machine in each stage and it must go through one or more stage. Machines in each stage can be identical, uniform or unrelated (Linn \& Zhang, 1999). The hybrid flow shop scheduling problem is NP-hard and it is usually solved by heuristic methods, that is based on simulated annealing, (Wang et al.) tabu search, and genetic algorithms. There has been a significant amount of research done on the HFS scheduling problem since its first attempt in 1971.

The main difference between the products of this production system and the other two is that the products of flow shop cannot be disassembled. In the other words, we do not have any assembly activity in flow shop systems but in job shop and Project production the product is divided to different components. We can see these components in the final product and finished goods but, in flow shop this issue is not obvious. So without visiting the production system, by observing only the final product, we can conclude whether this product is made in the flow shop or not.

\section{Methodology}

Makespan is one of the most important criteria in every production systems; it is equal to the total completion time of all the activities. Minimizing this criterion caused better usage of the resources specially machinery and manpower. In both simple and hybrid flow shop, the methodology is to convert the flow shop into a network form, then a linear programming model with the objective of minimizing the total completion time of all the activities are constructed. Minimizing total completion time of all the activities is equivalent 
to minimizing makespan in the production system. The result is that the sequencing and scheduling of all the activities are determined.

In the next step, some budget is assigned to crash the possible activities. It is possible that we can only assign budget to some of the activities to decrease their times. The amount of budget is always limited, so one question arises, and it is: what are the best activities to absorb this limited budget to minimize the total completion time of all the activities. This causes to add some more constraints to the problem and the result is that the critical activities are determined. The output of the problem is that how much budget should be assigned to which activities to get the best result. The best result is minimizing the total completion time of all the activities in the network which is equivalent to minimizing makespan.

\section{Minimizing makespan in simple flow shop scheduling using a network approach}

\subsection{Assumptions}

\subsubsection{Assumptions regarding the jobs}

- The sequencing model consists of a set of $\mathrm{n}$ jobs which are simultaneously available (at time zero, static environment).

- Job $\mathrm{r}$ has a predetermined operation times on machine $\mathrm{m} . \mathrm{m}=1, \ldots, \mathrm{M}$

- Set-up time is independent of sequence and is included in the processing time.

- Jobs are independent of each other.

- One unit of production for each job is considered.

\subsubsection{Assumptions regarding the machines}

- $\quad$ Each machine in the shop operates independently.

- Machines can be kept idle.

- All machines are continuously available.

- No machine breakdown is allowable.

- $\quad$ Each machine can process only one operation at a time point.

\subsubsection{Assumption regarding the process}

- Processing time for each job on each machine is deterministic and independent of the order in which jobs are to be processed.

- Transportation times of a job and set-up times are included in the processing time.

\section{Problem methodology}

\subsection{Problem definition}

In this chapter we are faced with a solved $n / m / F / C$ max problem. By using heuristics such as (Campbell et al.1970, Nawaz et al. 1983). To reminimize the makespan, processing times of the operations can be reduced by providing additional resources, which are available at a 
cost. The processing time of some of the operations can be reduced by assigning a cost. We would like to obtain minimum makespan by reducing processing time of some of these operations. The problem is to find these operations with a pre specified budget.

\subsection{Converting flow shop scheduling into a network}

Since we are interested in reducing makespan by employing additional resources crashing the project we develop a method to convert a flow shop scheduling into the project network.

Let us define the following notations to convert flow shop scheduling problems into a network.

\subsection{Nomenclature}

The following terminology is used for modeling the problem:

$\mathrm{N}$ : number of jobs.

M: number of machines.

$\mathrm{J}$ : an activity number.

m: machine number.

r: job number.

$\mathrm{J}_{\mathrm{rm}}$ : job $\mathrm{r}$ on machine $\mathrm{m}$.

$\mathrm{i}, \mathrm{j}$ : activity from node $\mathrm{i}$ to node $\mathrm{j}$.

Tj: starting time of node $j$.

Di,j: normal duration time of activity from node $i$ to node $j$.

Df(i,j): minimum crashing time of activity $i$ to $j$.

$\mathrm{d}_{\mathrm{i}, \mathrm{j}}$ : crashed duration time of activity $\mathrm{i}$ to $\mathrm{j}$.

$\mathrm{C}_{\mathrm{i}, \mathrm{j}}$ : slope of crashing cost for activity $\mathrm{i}$ to $\mathrm{j}$.

B: predetermined budget.

\subsection{Network requirements}

Certainly when flow shop scheduling problem is converted into a network, it is important to prepare network requirement. Thus, let us define network requirement as follows:

Nodes: Each node represents an event of start or finish operation(s) on machines.

Activity: Activities are the operations to be done on specific machine and have duration equal to processing time.

Predecessors: Activity representing the previous operation for the same job constitutes a preceding activity to the operation. Further the activity corresponding to the operation of the job on the same machine which is before this job in the sequence also constitutes preceding activity.

Duration time: "processing time" is the duration of the activity.

Resources: Machines are the resources.

Suppose we have a flow shop system with $\mathrm{n}$ jobs and $\mathrm{m}$ machines. The data is described in table 1. 


\begin{tabular}{|c|c|c|c|}
\hline Activity & Predecessors & Duration Time & Machine \\
\hline 1,1 & --- & $\mathrm{D}_{11}$ & $\mathrm{M}_{1}$ \\
$\cdot$ & $\cdot$ & $\cdot$ & $\cdot$ \\
$\mathrm{i}, \mathrm{j}$ & $(\mathrm{i}, \mathrm{j}-1),(\mathrm{i}-1, \mathrm{j})$ & $\cdot$ & $\cdot$ \\
$\cdot$ & $\cdot$ & $\mathrm{D}_{\mathrm{ij}}$ & $\mathrm{M}_{\mathrm{j}}$ \\
$\cdot$ & $\cdot$ & $\cdot$ & $\cdot$ \\
$\mathrm{r}, \mathrm{m}$ & $(\mathrm{r}, \mathrm{m}-1),(\mathrm{r}-1, \mathrm{~m})$ & $\cdot$ & $\mathrm{M}_{\mathrm{m}}$ \\
\hline
\end{tabular}

Table 1. Data for general model

\subsection{Linear programming application to find minimum makespan subject to budget limitation}

According to objective that is to select operations to be crashed for finding minimum makespan subject to budget limitation, after converting flow shop scheduling problem into the network, now it is possible to crash the network to find minimum makespan.

\subsection{Problem formulation}

The problem can be formulated as follows:

$$
\begin{gathered}
\text { MinZ }=T_{n}-T_{1} \\
S T . \\
\sum \sum C_{i, j}\left(D_{i, j}-d_{i, j}\right) \leq B \\
T_{j}-T_{i} \geq d_{i, j} \\
D_{f(i, j)} \leq d_{i, j} \leq D_{i, j} \\
T_{i}, T_{j}, d_{i, j}=\text { integer }
\end{gathered}
$$

Constraint (1) is related to budget limitation, that additional cost for crashing could not be greater than pre specified budget. Constraint (2) states that the start time of event $\mathrm{j}$ should be at least equal to start time of $i$ and crash duration of activity $i-j$. Constraint (3) is related to the lower and upper bounds on crash duration.

It is obvious that all $t_{i}$ 's and $d i j$ must be non negative and also integer. However, due to structure of the problem, it can be solved as a linear programming problem.

\subsection{Converting the flow shop problems into a network}

In next section we have shown how to convert flow shop problems to project network. We can calculate the earliest start, latest start, floats for all the activities using CPM method. Earliest finishing time of the project is equal to makespan for the flow shop problem. After that we can use the linear programming model for crashing the network. 


\section{Numerical example}

Consider that we have a flow shop problem with four machines and five jobs. According to Campbell et al. (1970), the sequence has been obtained as A-B-C-E-D with corresponding processing times as given in table 2 .

\begin{tabular}{|c|c|c|c|c|c|}
\hline & \multicolumn{4}{|c|}{ MACHINE } \\
\hline & & $\begin{array}{l}\text { Cutting } \\
\text { (min) }\end{array}$ & $\begin{array}{c}\text { Pressing } \\
\text { (min) }\end{array}$ & $\begin{array}{c}\text { Drilling } \\
\text { (min) }\end{array}$ & $\begin{array}{l}\text { Welding } \\
\text { (min) }\end{array}$ \\
\hline \multirow{5}{*}{$\stackrel{\infty}{0}$} & Part A & 5 & 6 & 8 & 4 \\
\hline & Part B & 7 & 5 & 7 & 3 \\
\hline & Part C & 6 & 3 & 5 & 3 \\
\hline & Part D & 8 & 3 & 2 & 3 \\
\hline & Part E & 7 & 4 & 3 & 4 \\
\hline
\end{tabular}

Table 2. Processing time of a flow shop with 4 machines and 5 jobs.

Conversion of this problem to a CPM network with information of prerequisite is given in table 3 and the corresponding network is shown in figure 1.

\begin{tabular}{|c|c|c|c|}
\hline Node $(\mathrm{i}, \mathrm{j})$ & Activity $\left(\mathrm{J}_{\mathrm{rm}}\right)$ & Predecessor & Duration time $\left(\mathrm{D}_{\mathrm{i}, \mathrm{j}}\right)$ \\
\hline 1,2 & $\mathrm{~J}_{\mathrm{A} 1}$ & --- & 5 \\
\hline 2,3 & $\mathrm{~J}_{\mathrm{B} 1}$ & $\mathrm{~J}_{\mathrm{A} 1}$ & 7 \\
\hline 3,4 & $\mathrm{~J}_{\mathrm{C} 1}$ & $\mathrm{~J}_{\mathrm{B} 1}$ & 7 \\
\hline 4,5 & $\mathrm{~J}_{\mathrm{E} 1}$ & $\mathrm{~J}_{\mathrm{C} 1}$ & 8 \\
\hline 5,6 & $\mathrm{~J}_{\mathrm{D} 1}$ & $\mathrm{~J}_{\mathrm{E} 1}$ & 6 \\
\hline 2,7 & $\mathrm{~J}_{\mathrm{A} 2}$ & $\mathrm{~J}_{\mathrm{A} 1}$ & 5 \\
\hline 8,9 & $\mathrm{~J}_{\mathrm{B} 2}$ & $\mathrm{~J}_{\mathrm{B} 1} \mathrm{~J}_{\mathrm{A} 2}$ & 3 \\
\hline 10,11 & $\mathrm{~J}_{\mathrm{C} 2}$ & $\mathrm{~J}_{\mathrm{C} 1} \mathrm{~J}_{\mathrm{B} 2}$ & 4 \\
\hline 12,13 & $\mathrm{~J}_{\mathrm{E} 2}$ & $\mathrm{~J}_{\mathrm{E} 1} \mathrm{~J}_{\mathrm{C} 2}$ & 3 \\
\hline 14,15 & $\mathrm{~J}_{\mathrm{D} 2}$ & $\mathrm{~J}_{\mathrm{D} 1} \mathrm{~J}_{\mathrm{E} 2}$ & 8 \\
\hline 7,16 & $\mathrm{~J}_{\mathrm{A} 3}$ & $\mathrm{~J}_{\mathrm{A} 2}$ & 5 \\
\hline 17,18 & $\mathrm{~J}_{\mathrm{B} 3}$ & $\mathrm{~J}_{\mathrm{B} 2} \mathrm{~J}_{\mathrm{A} 3}$ & 3 \\
\hline 19,20 & $\mathrm{~J}_{\mathrm{C} 3}$ & $\mathrm{~J}_{\mathrm{C} 2} \mathrm{~J}_{\mathrm{B} 3}$ & 2 \\
\hline 21,22 & $\mathrm{~J}_{\mathrm{E} 3}$ & $\mathrm{~J}_{\mathrm{E} 2} \mathrm{~J}_{\mathrm{C} 3}$ & 4 \\
\hline 23,24 & $\mathrm{~J}_{\mathrm{D} 3}$ & $\mathrm{~J}_{\mathrm{D} 2} \mathrm{~J}_{\mathrm{E} 3}$ & 3 \\
\hline 16,25 & $\mathrm{~J}_{\mathrm{A} 4}$ & $\mathrm{~J}_{\mathrm{A} 3}$ & 3 \\
\hline 25,26 & $\mathrm{~J}_{\mathrm{B} 4}$ & $\mathrm{~J}_{\mathrm{B} 33} \mathrm{~J}_{\mathrm{A} 4}$ & 4 \\
\hline 26,27 & $\mathrm{~J}_{\mathrm{C} 4}$ & $\mathrm{~J}_{\mathrm{C} 3} \mathrm{~J}_{\mathrm{B} 4}$ & 3 \\
\hline 27,28 & $\mathrm{~J}_{\mathrm{E} 4}$ & $\mathrm{~J}_{\mathrm{E} 3} \mathrm{~J}_{\mathrm{C} 4}$ & \\
\hline 28,29 & $\mathrm{~J}_{\mathrm{D} 4}$ & $\mathrm{~J}_{\mathrm{D} 3} \mathrm{~J}_{\mathrm{E} 4}$ & \\
\hline
\end{tabular}

Table 3. The project network data for corresponding example. 


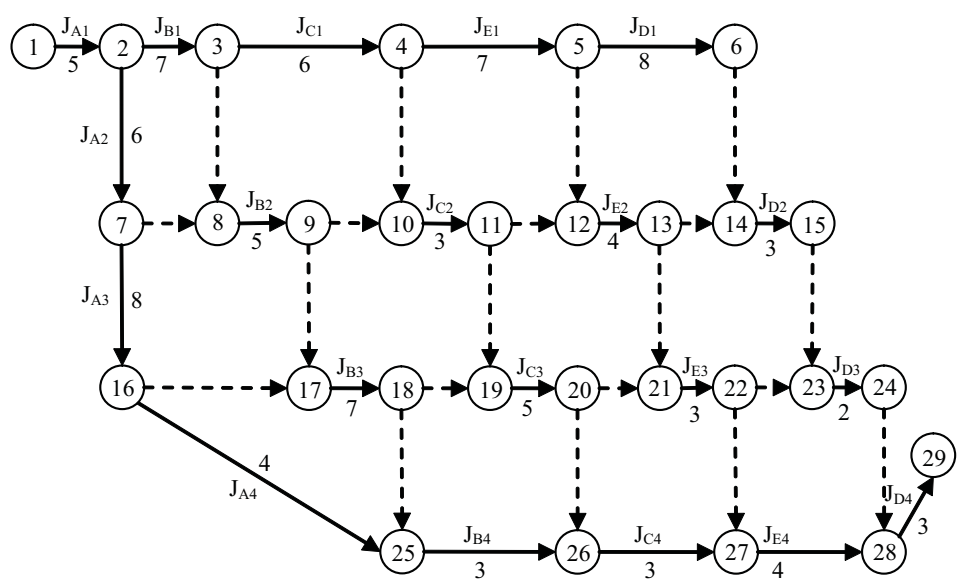

Fig. 1. Project network for given example

- - D : Dummy operation is used to consider the technological constraints.

Now we should assign some budget to some activities (operation) for which their time can be reduced. These are shown in table 4 .

\begin{tabular}{|c|c|c|c|c|c|}
\hline $\begin{array}{c}\text { Node } \\
(\mathrm{i}, \mathrm{j})\end{array}$ & $\begin{array}{c}\text { Activity } \\
\left(\mathrm{J}_{\mathrm{rm}}\right)\end{array}$ & Predecessor & $\begin{array}{c}\text { Duration } \\
\text { time }\left(\mathrm{D}_{\mathrm{i}, \mathrm{j}}\right)\end{array}$ & $\begin{array}{c}\text { Minimum } \\
\text { Duration } \\
\text { time }\left(\mathrm{D}_{\mathrm{f}(\mathrm{i}, \mathrm{j})}\right)\end{array}$ & $\begin{array}{c}\text { Cost } \\
\text { Slope } \\
(\$)\end{array}$ \\
\hline 1,2 & $\mathrm{~J}_{\mathrm{A} 1}$ & --- & 5 & 4 & 1150 \\
\hline 2,3 & $\mathrm{~J}_{\mathrm{B} 1}$ & $\mathrm{~J}_{\mathrm{A} 1}$ & 7 & 3 & 1400 \\
\hline 3,4 & $\mathrm{~J}_{\mathrm{C} 1}$ & $\mathrm{~J}_{\mathrm{B} 1}$ & 6 & 6 & --- \\
\hline 4,5 & $\mathrm{~J}_{\mathrm{E} 1}$ & $\mathrm{~J}_{\mathrm{C} 1}$ & 7 & 5 & 1100 \\
\hline 5,6 & $\mathrm{~J}_{\mathrm{D} 1}$ & $\mathrm{~J}_{\mathrm{E} 1}$ & 8 & 8 & --- \\
\hline 2,7 & $\mathrm{~J}_{\mathrm{A} 2}$ & $\mathrm{~J}_{\mathrm{A} 1}$ & 6 & 4 & 900 \\
\hline 8,9 & $\mathrm{~J}_{\mathrm{B} 2}$ & $\mathrm{~J}_{\mathrm{B} 1} \mathrm{~J}_{\mathrm{A} 2}$ & 5 & 5 & --- \\
\hline 10,11 & $\mathrm{~J}_{\mathrm{C} 2}$ & $\mathrm{~J}_{\mathrm{C} 1, \mathrm{~J}_{\mathrm{B} 2}}$ & 3 & 3 & --- \\
\hline 12,13 & $\mathrm{~J}_{\mathrm{E} 2}$ & $\mathrm{~J}_{\mathrm{E} 1} \mathrm{~J}_{\mathrm{C} 2}$ & 4 & 4 & --- \\
\hline 14,15 & $\mathrm{~J}_{\mathrm{D} 2}$ & $\mathrm{~J}_{\mathrm{D} 1} \mathrm{~J}_{\mathrm{E} 2}$ & 3 & 3 & --- \\
\hline 7,16 & $\mathrm{~J}_{\mathrm{A} 3}$ & $\mathrm{~J}_{\mathrm{A} 2}$ & 8 & 6 & 1000 \\
\hline 17,18 & $\mathrm{~J}_{\mathrm{B} 3}$ & $\mathrm{~J}_{\mathrm{B} 2} \mathrm{~J}_{\mathrm{A} 3}$ & 7 & 7 & --- \\
\hline 19,20 & $\mathrm{~J}_{\mathrm{C} 3}$ & $\mathrm{~J}_{\mathrm{C} 2} \mathrm{~J}_{\mathrm{B} 3}$ & 5 & 4 & 1300 \\
\hline 21,22 & $\mathrm{~J}_{\mathrm{E} 3}$ & $\mathrm{~J}_{\mathrm{E} 2} \mathrm{~J}_{\mathrm{C} 3}$ & 3 & 3 & --- \\
\hline 23,24 & $\mathrm{~J}_{\mathrm{D} 3}$ & $\mathrm{~J}_{\mathrm{D} 2} \mathrm{~J}_{\mathrm{E} 3}$ & 2 & 2 & --- \\
\hline 16,25 & $\mathrm{~J}_{\mathrm{A} 4}$ & $\mathrm{~J}_{\mathrm{A} 3}$ & 4 & 4 & --- \\
\hline 25,26 & $\mathrm{~J}_{\mathrm{B} 4}$ & $\mathrm{~J}_{\mathrm{B} 3} \mathrm{~J}_{\mathrm{A} 4}$ & 3 & 3 & --- \\
\hline 26,27 & $\mathrm{~J}_{\mathrm{C} 4}$ & $\mathrm{~J}_{\mathrm{C} 3} \mathrm{~J}_{\mathrm{B} 4}$ & 3 & 2 & 1600 \\
\hline 27,28 & $\mathrm{~J}_{\mathrm{E} 4}$ & $\mathrm{~J}_{\mathrm{E} 33} \mathrm{~J}_{\mathrm{C} 4}$ & 4 & 4 & --- \\
\hline 28,29 & $\mathrm{~J}_{\mathrm{D} 4}$ & $\mathrm{~J}_{\mathrm{D} 3} \mathrm{~J}_{\mathrm{E} 4}$ & 3 & 3 & -- \\
\hline
\end{tabular}

Table 4. Cost of reduced times 


\subsection{Problem solution}

Considering the information given for the problem in tables 3 and 4 and Fig. 1 the objective function and the constraints can be written as follows:

$\operatorname{MinZ}=T_{29}-T_{1}$

S. to :

$$
\begin{aligned}
& 1150 \times\left(5-d_{12}\right)+1400 \times\left(7-d_{23}\right)+1100 \times\left(7-d_{45}\right)+900 \times\left(6-d_{27}\right)+1000 \times\left(8-d_{716}\right)+ \\
& 1300 \times\left(5-d_{1920}\right)+1600 \times\left(3-d_{2627}\right) \leq 7000
\end{aligned}
$$

$\begin{array}{ll}T_{2}-T_{1} \geq d_{12} & T_{26}-T_{25} \geq d_{2526} \\ T_{3}-T_{2} \geq d_{23} & T_{27}-T_{26} \geq d_{2627} \\ T_{4}-T_{3} \geq d_{34} & T_{28}-T_{27} \geq d_{2728} \\ T_{5}-T_{4} \geq d_{45} & T_{29}-T_{28} \geq d_{2829} \\ T_{6}-T_{5} \geq d_{56} & T_{8}-T_{3} \geq 0 \\ T_{7}-T_{2} \geq d_{27} & T_{10}-T_{4} \geq 0 \\ T_{9}-T_{8} \geq d_{89} & T_{8}-T_{7} \geq 0 \\ T_{11}-T_{10} \geq d_{1011} & T_{10}-T_{9} \geq 0 \\ T_{13}-T_{12} \geq d_{1213} & T_{12}-T_{11} \geq 0 \\ T_{15}-T_{14} \geq d_{1415} & T_{12}-T_{5} \geq 0 \\ T_{16}-T_{7} \geq d_{716} & T_{14}-T_{13} \geq 0 \\ T_{18}-T_{17} \geq d_{1718} & T_{14}-T_{6} \geq 0 \\ T_{20}-T_{19} \geq d_{1920} & T_{17}-T_{9} \geq 0 \\ T_{22}-T_{21} \geq d_{2122} & T_{17}-T_{16} \geq 0 \\ T_{24}-T_{23} \geq d_{2324} & T_{19}-T_{18} \geq 0 \\ T_{25}-T_{16} \geq d_{1625} & T_{19}-T_{11} \geq 0 \\ T_{21}-T_{20} \geq 0 & \\ T_{21}-T_{13} \geq 0 & \\ T_{23}-T_{22} \geq 0 & d_{56}=8 \\ T_{23}-T_{15} \geq 0 & d_{89}=5 \\ T_{25}-T_{18} \geq 0 & d_{1011}=3 \\ T_{26}-T_{20} \geq 0 & d_{1213}=4 \\ T_{27}-T_{22} \geq 0 & d_{1415}=3 \\ T_{28}-T_{24} \geq 0 & d_{1718}=7 \\ 4 \leq d_{12} \leq 5 & d_{2122}=3 \\ 3 \leq d_{23} \leq 7 & d_{2324}=2 \\ 5 \leq d_{45} \leq 7 & d_{1625}=4 \\ 4 \leq d_{27} \leq 6 & d_{2526}=3 \\ 6 \leq d_{716} \leq 8 & d_{2728}=4 \\ 4 \leq d_{1920} \leq 5 & d_{2829}=3 \\ 2 \leq d_{2627} \leq 3 & \\ d_{34}=6 & \\ & \\ & \end{array}$




\subsection{Results}

The results are given using LINGO 7.0 optimally. In table 5, optimum duration for each activity is given. According to budget limitation makespan could be reduced from 41 (before crashing) to 38 .

\begin{tabular}{|c|c|c|}
\hline Node $(\mathrm{i}, \mathrm{j})$ & Activity $\left(\mathrm{J}_{\mathrm{rm}}\right)$ & $\begin{array}{c}\text { Crashed Duration } \\
\text { time }\left(\mathrm{d}_{\mathrm{i}, \mathrm{j}}\right)\end{array}$ \\
\hline 1,2 & $\mathrm{~J}_{\mathrm{A} 1}$ & 4 \\
\hline 2,3 & $\mathrm{~J}_{\mathrm{B} 1}$ & 7 \\
\hline 3,4 & $\mathrm{~J}_{\mathrm{C} 1}$ & 6 \\
\hline 4,5 & $\mathrm{~J}_{\mathrm{E} 1}$ & 5 \\
\hline 5,6 & $\mathrm{~J}_{\mathrm{D} 1}$ & 8 \\
\hline 2,7 & $\mathrm{~J}_{\mathrm{A} 2}$ & 5 \\
\hline 8,9 & $\mathrm{~J}_{\mathrm{B} 2}$ & 3 \\
\hline 10,11 & $\mathrm{~J}_{\mathrm{C} 2}$ & 4 \\
\hline 12,13 & $\mathrm{~J}_{\mathrm{E} 2}$ & 3 \\
\hline 14,15 & $\mathrm{~J}_{\mathrm{D} 2}$ & 6 \\
\hline 7,16 & $\mathrm{~J}_{\mathrm{A} 3}$ & 7 \\
\hline 17,18 & $\mathrm{~J}_{\mathrm{B} 3}$ & 5 \\
\hline 19,20 & $\mathrm{~J}_{\mathrm{C} 3}$ & 3 \\
\hline 21,22 & $\mathrm{~J}_{\mathrm{E} 3}$ & 2 \\
\hline 23,24 & $\mathrm{~J}_{\mathrm{D} 3}$ & 4 \\
\hline 16,25 & $\mathrm{~J}_{\mathrm{A} 4}$ & 3 \\
\hline 25,26 & $\mathrm{~J}_{\mathrm{B} 4}$ & 3 \\
\hline 26,27 & $\mathrm{~J}_{\mathrm{C} 4}$ & 4 \\
\hline 27,28 & $\mathrm{~J}_{\mathrm{E} 4}$ & 3 \\
\hline 28,29 & $\mathrm{~J}_{\mathrm{D} 4}$ & \\
\hline
\end{tabular}

Table 5. Optimal duration for each activity according to budget limitation

Table 6 demonstrates different minimum makespan according to different budget assignment.

\begin{tabular}{|c|c|}
\hline Budget (\$) & Makespan \\
\hline 0 & 41 \\
\hline 2000 & 40 \\
\hline 4000 & 39 \\
\hline 6000 & 38 \\
\hline 7000 & 38 \\
\hline
\end{tabular}

Table 6. Minimum makespan according to the budget

\section{Minimizing makespan in hybrid flow shop scheduling using a network approach}

\subsection{Assumptions}

\subsubsection{Assumptions regarding the jobs}

- The sequencing model consists of a set of $\mathrm{n}$ jobs which are simultaneously available (at time zero, static environment). 
- Job $\mathrm{r}$ has a predetermined operation times on machine $\mathrm{m}$.

- Set-up time is independent of sequence and is included in the processing time.

- Jobs are independent of each other.

- (Shortest Processing Time) SPT rule is used to assign the jobs to the machines.

- One unit of production for each job is considered.

\subsubsection{Assumptions regarding the machines}

- $\quad$ Each machine in the shop operates independently.

- Machines can be kept idle.

- All machines are continuously available.

- No machine breakdown is allowable.

- Each machine can process only one operation at a time point.

- $\quad$ Each machine starts at its earliest starting time possible.

- Interruption of the machines is not allowed (no repairing during processing).

\subsubsection{Assumption regarding the process}

- Processing time for each job on each machine is deterministic and independent of the order in which jobs are to be processed.

- Transportation times of a job and set-up times are included in the processing time.

\subsection{Nomenclature}

The following terminology is used for modeling the problem:

$\mathrm{N}$ : number of jobs.

M: number of machines.

$\mathrm{J}$ : an activity number.

m: machine number.

r: job number.

s: stage number.

$\mathrm{J}_{\mathrm{rms}}$ : job $\mathrm{r}$ on machine $\mathrm{m}$ in stage $\mathrm{s}$.

$i, j$ : activity from node $i$ to node $j$.

Tj: starting time of node $\mathrm{j}$.

Di,j: normal duration time of activity from node $i$ to node $j$.

Df(i,j): minimum crashing time of activity $i$ to $j$.

$d_{i, j}$ : crashed duration time of activity $i$ to $j$.

$\mathrm{C}_{\mathrm{i}, \mathrm{j}}$ : slope of crashing cost for activity $\mathrm{i}$ to $\mathrm{j}$.

B: predetermined budget.

\subsection{Converting H.F.S. into a network model}

We can illustrate a general form of H.F.S. with $\mathrm{n}$ jobs $\mathrm{m}$ machines, and s stages as in Fig. 2

Each operation has a predecessor which is shown in table 7. There are two sets of predecessors, one, the operational constraint, for which every job should be processed in its earlier stage, and second technological constraint for which each machine should operate the jobs in chronological order. 


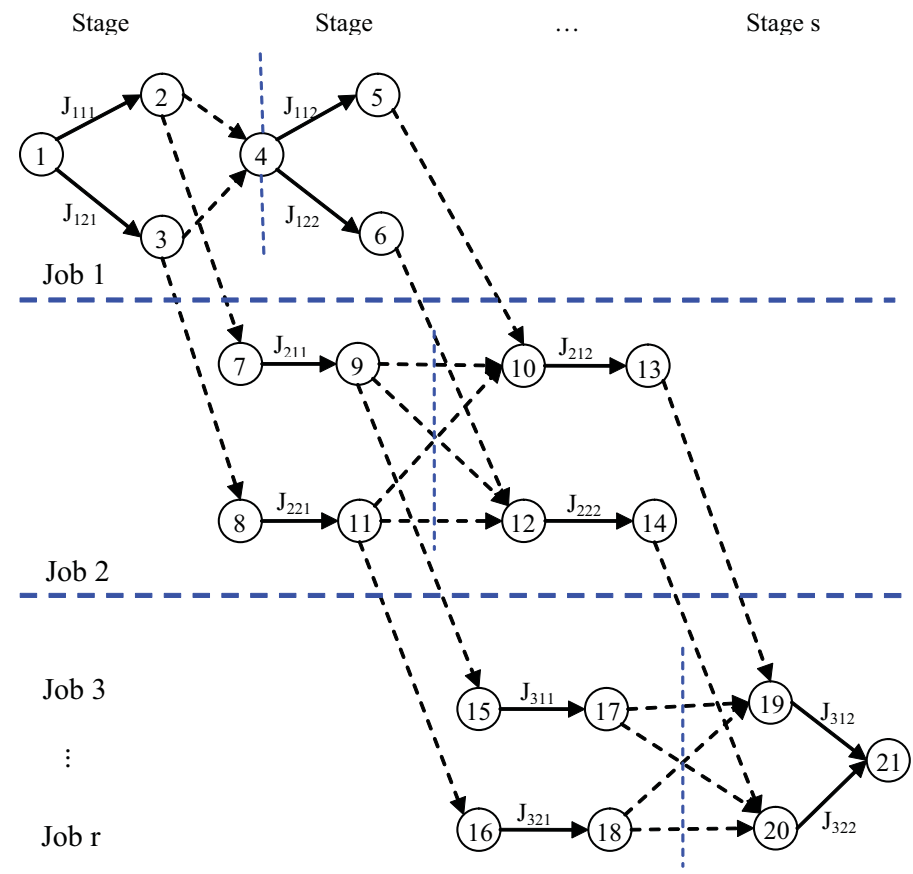

Fig. 2. General model of H.F.S.

\begin{tabular}{|c|c|c|c|}
\hline Stage & activity & predecessor & $\begin{array}{c}\text { Duration } \\
\text { time }\end{array}$ \\
\hline \multirow{3}{*}{1} & $\mathrm{~J}_{1 \mathrm{~m} 1}$ & $\begin{array}{l}\mathrm{J}_{\mathrm{rm} 1} \quad \mathrm{~m}=1 \text { or } 2 \text { or } \ldots \text { or } \mathrm{M}, \mathrm{r}=1 \\
\mathrm{~J}_{\mathrm{rms}} \quad \mathrm{m}=1,2, \ldots, \mathrm{M}, \mathrm{r}=1, \mathrm{~s}=\mathrm{s}-1\end{array}$ & $\mathrm{D}_{1 \mathrm{~m} 1}$ \\
\hline & $\mathrm{J}_{\mathrm{rm} 1}$ & $\begin{array}{ll}\mathrm{J}_{\mathrm{rm} 1} & \mathrm{~m}=1 \text { or } 2 \text { or } \ldots \text { or } \mathrm{M}, \mathrm{r}=1,2, \ldots, \mathrm{r}-1 \\
\mathrm{~J}_{\mathrm{rms}} & \mathrm{m}=1,2, \ldots, \mathrm{M}, \mathrm{r}=\mathrm{r}, \mathrm{s}=\mathrm{s}-1\end{array}$ & $\mathrm{D}_{\mathrm{rm} 1}$ \\
\hline & $\mathrm{J}_{\mathrm{Nm} 1}$ & $\begin{array}{l}\mathrm{J}_{\mathrm{rm} 1} \quad \mathrm{~m}=1 \text { or } 2 \text { or } \ldots \text { or } \mathrm{M}, \mathrm{r}=1,2, \ldots, \mathrm{N}-1 \\
\mathrm{~J}_{\mathrm{rms}} \quad \mathrm{m}=1,2, \ldots, \mathrm{M}, \mathrm{r}=\mathrm{N}, \mathrm{s}=\mathrm{s}-1\end{array}$ & $\mathrm{D}_{\mathrm{Nm} 1}$ \\
\hline \multirow{3}{*}{2} & $\mathrm{~J}_{1 \mathrm{~m} 2}$ & $\begin{array}{ll}\mathrm{J}_{\mathrm{rm} 2} & \mathrm{~m}=1 \text { or } 2 \text { or } \ldots \text { or } \mathrm{M}, \mathrm{r}=1 \\
\mathrm{~J}_{\mathrm{rms}} & \mathrm{m}=1,2, \ldots, \mathrm{M}, \mathrm{r}=1, \mathrm{~s}=\mathrm{s}-1\end{array}$ & $\mathrm{D}_{1 \mathrm{~m} 2}$ \\
\hline & $\mathrm{J}_{\mathrm{rm} 2}$ & $\begin{array}{ll}\mathrm{J}_{\mathrm{rm} 2} & \mathrm{~m}=1 \text { or } 2 \text { or } \ldots \text { or } \mathrm{M}, \mathrm{r}=1,2, \ldots, \mathrm{r}-1 \\
\mathrm{~J}_{\mathrm{rms}} & \mathrm{m}=1,2, \ldots, \mathrm{M}, \mathrm{r}=\mathrm{r}, \mathrm{s}=\mathrm{s}-1\end{array}$ & $\mathrm{D}_{\mathrm{rm} 2}$ \\
\hline & $\mathrm{J}_{\mathrm{Nm} 2}$ & $\begin{array}{l}\mathrm{J}_{\mathrm{rm} 2} \quad \mathrm{~m}=1 \text { or } 2 \text { or } \ldots \text { or } \mathrm{M}, \mathrm{r}=1,2, \ldots, \mathrm{N}-1 \\
\mathrm{~J}_{\mathrm{rms}} \quad \mathrm{m}=1,2, \ldots, \mathrm{M}, \mathrm{r}=\mathrm{N}, \mathrm{s}=\mathrm{s}-1\end{array}$ & $\mathrm{D}_{\mathrm{Nm} 2}$ \\
\hline
\end{tabular}

Table 7. Predecessors for general model 


\subsection{Problem formulation}

The problem can be formulated as follows:

$$
\begin{aligned}
& \operatorname{MinZ}=T_{n}-T_{1} \\
& S T . \\
& \sum \sum C_{i, j}\left(D_{i, j}-d_{i, j}\right) \leq B \\
& T_{j}-T_{i} \geq d_{i, j} \\
& D_{f(i, j)} \leq d_{i, j} \leq D_{i, j} \\
& T_{i}, T_{j}, d_{i, j}=\text { integer }
\end{aligned}
$$

\section{Numerical example}

The methodology is illustrated using a numerical example with 4 jobs, 4 stages and respectively 3,4,3 and 2 machines in each stage. The problem is solved using SPT (Shortest Processing Time). The sequence has been obtained as A-C-B-D with corresponding processing times as given in table 8 .

\begin{tabular}{|c|c|c|c||c|c|c|c||c|c|c||c|c|}
\hline \multirow{2}{*}{ Job } & \multicolumn{3}{|c||}{ Stage 1 } & \multicolumn{4}{c||}{ Stage 2 } & \multicolumn{3}{c||}{ Stage 3 } & \multicolumn{2}{|c|}{ Stage 4 } \\
\cline { 2 - 13 } & M1 & M2 & M3 & M1 & M2 & M3 & M4 & M1 & M2 & M3 & M1 & M2 \\
\hline $\begin{array}{c}\text { Part } \\
\text { A }\end{array}$ & 10 & 12 & 8 & 7 & 10 & 11 & 15 & 9 & 7 & 8 & 20 & 17 \\
\hline $\begin{array}{c}\text { Part } \\
\text { B }\end{array}$ & 8 & 14 & 11 & 8 & 9 & 14 & 16 & 11 & 6 & 10 & 18 & 19 \\
\hline $\begin{array}{c}\text { Part } \\
\text { C }\end{array}$ & 13 & 9 & 10 & 13 & 9 & 15 & 8 & 8 & 10 & 6 & 21 & 16 \\
\hline $\begin{array}{c}\text { Part } \\
\text { D }\end{array}$ & 9 & 11 & 15 & 14 & 16 & 7 & 11 & 9 & 10 & 11 & 19 & 16 \\
\hline
\end{tabular}

Table 8. Processing time

The network is illustrated in Fig. 3

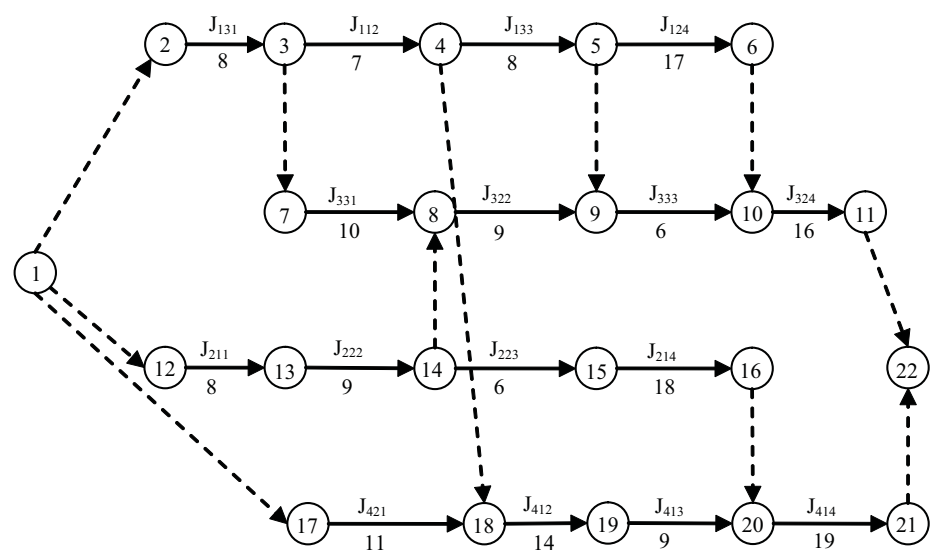

Fig. 3. The network of numerical example 
For this problem the predecessors are shown in table 9.

\begin{tabular}{|c|c|c|c|}
\hline Node $(\mathrm{i}, \mathrm{j})$ & Activity $\left(\mathrm{J}_{\text {rms }}\right)$ & Predecessor & Duration time $\left(\mathrm{D}_{\mathrm{i}, \mathrm{j}}\right)$ \\
\hline 2,3 & $\mathrm{~J}_{131}$ & --- & 8 \\
\hline 3,4 & $\mathrm{~J}_{112}$ & $\mathrm{~J}_{131}$ & 7 \\
\hline 4,5 & $\mathrm{~J}_{133}$ & $\mathrm{~J}_{112}$ & 17 \\
\hline 5,6 & $\mathrm{~J}_{124}$ & $\mathrm{~J}_{133}$ & 10 \\
\hline 7,8 & $\mathrm{~J}_{331}$ & $\mathrm{~J}_{131}$ & 9 \\
\hline 8,9 & $\mathrm{~J}_{322}$ & $\mathrm{~J}_{331}, \mathrm{~J}_{222}$ & 6 \\
\hline 9,10 & $\mathrm{~J}_{333}$ & $\mathrm{~J}_{322}, \mathrm{~J}_{133}$ & 16 \\
\hline 10,11 & $\mathrm{~J}_{324}$ & $\mathrm{~J}_{333}, \mathrm{~J}_{124}$ & 8 \\
\hline 12,13 & $\mathrm{~J}_{211}$ & --- & 6 \\
\hline 13,14 & $\mathrm{~J}_{222}$ & $\mathrm{~J}_{211}$ & 18 \\
\hline 14,15 & $\mathrm{~J}_{223}$ & $\mathrm{~J}_{222}$ & 11 \\
\hline 15,16 & $\mathrm{~J}_{214}$ & $\mathrm{~J}_{223}$ & 14 \\
\hline 17,18 & $\mathrm{~J}_{421}$ & --- & 9 \\
\hline 18,19 & $\mathrm{~J}_{412}$ & $\mathrm{~J}_{421}, \mathrm{~J}_{112}$ & 19 \\
\hline 19,20 & $\mathrm{~J}_{413}$ & $\mathrm{~J}_{412}$ & \\
\hline 20,21 & $\mathrm{~J}_{414}$ & $\mathrm{~J}_{413}, \mathrm{~J}_{214}$ & \\
\hline
\end{tabular}

Table 9. Predecessor of the numerical example

Now we should assign some budget to some activities (operation) for which their time can be reduced. These are shown in table 10.

\begin{tabular}{|c|c|c|c|c|c|}
\hline $\begin{array}{c}\text { Node } \\
(\mathrm{i}, \mathrm{j})\end{array}$ & $\begin{array}{c}\text { Activity } \\
\left(\mathrm{J}_{\mathrm{rms}}\right)\end{array}$ & Predecessor & $\begin{array}{c}\text { Duration time } \\
\left(\mathrm{D}_{\mathrm{i}, \mathrm{j}}\right)\end{array}$ & $\begin{array}{c}\text { Minimum } \\
\text { Duration Time } \\
\left(\mathrm{D}_{\mathrm{f}(\mathrm{i}, \mathrm{j})}\right)\end{array}$ & $\begin{array}{c}\text { Cost Slope } \\
(\$)\end{array}$ \\
\hline 2,3 & $\mathrm{~J}_{131}$ & --- & 8 & 6 & 1200 \\
\hline 3,4 & $\mathrm{~J}_{112}$ & $\mathrm{~J}_{131}$ & 7 & 7 & -- \\
\hline 4,5 & $\mathrm{~J}_{133}$ & $\mathrm{~J}_{112}$ & 8 & 5 & 1500 \\
\hline 5,6 & $\mathrm{~J}_{124}$ & $\mathrm{~J}_{133}$ & 17 & 14 & --- \\
\hline 7,8 & $\mathrm{~J}_{331}$ & $\mathrm{~J}_{131}$ & 10 & 10 & -- \\
\hline 8,9 & $\mathrm{~J}_{322}$ & $\mathrm{~J}_{331}, \mathrm{~J}_{222}$ & 9 & 9 & --- \\
\hline 9,10 & $\mathrm{~J}_{333}$ & $\mathrm{~J}_{322}, \mathrm{~J}_{133}$ & 6 & 6 & --- \\
\hline 10,11 & $\mathrm{~J}_{324}$ & $\mathrm{~J}_{333}, \mathrm{~J}_{124}$ & 16 & 14 & -- \\
\hline 12,13 & $\mathrm{~J}_{211}$ & --- & 8 & 8 & -- \\
\hline 13,14 & $\mathrm{~J}_{222}$ & $\mathrm{~J}_{211}$ & 9 & 7 & 2100 \\
\hline 14,15 & $\mathrm{~J}_{223}$ & $\mathrm{~J}_{222}$ & 6 & 6 & --- \\
\hline 15,16 & $\mathrm{~J}_{214}$ & $\mathrm{~J}_{223}$ & 18 & 15 & 1800 \\
\hline 17,18 & $\mathrm{~J}_{421}$ & --- & 11 & 9 & -- \\
\hline 18,19 & $\mathrm{~J}_{412}$ & $\mathrm{~J}_{421}, \mathrm{~J}_{112}$ & 14 & 14 & --- \\
\hline 19,20 & $\mathrm{~J}_{413}$ & $\mathrm{~J}_{412}$ & 9 & 7 & 2000 \\
\hline 20,21 & $\mathrm{~J}_{414}$ & $\mathrm{~J}_{413}, \mathrm{~J}_{214}$ & 19 & 17 & 1600 \\
\hline
\end{tabular}

Table 10. Cost of reduced times 


\subsection{Problem solution}

Considering the information given for the problem in tables 9 and 10 and Fig. 3, the objective function and the constraints can be written as follows:

$$
\operatorname{MinZ}=T_{22}-T_{1}
$$

Subject To:

$$
\begin{aligned}
& 1200 \times\left(8-d_{23}\right)+1500 \times\left(8-d_{45}\right)+1800 \times\left(18-d_{1516}\right)+2000 \times\left(9-d_{1920}\right)+2100 \times\left(9-d_{1314}\right) \\
& +1600 \times\left(19-d_{2021}\right) \leq 10000
\end{aligned}
$$

$$
\begin{array}{ll}
T_{3}-T_{2} \geq d_{23} & 6 \leq d_{23} \leq 8 \\
T_{4}-T_{3} \geq d_{34} & 5 \leq d_{45} \leq 8 \\
T_{5}-T_{4} \geq d_{45} & 7 \leq d_{1314} \leq 9 \\
T_{6}-T_{5} \geq d_{56} & 15 \leq d_{1516} \leq 18 \\
T_{8}-T_{7} \geq d_{78} & 7 \leq d_{1920} \leq 9 \\
T_{9}-T_{8} \geq d_{89} & 17 \leq d_{2021} \leq 19 \\
T_{10}-T_{9} \geq d_{910} & d_{56}=17 \\
T_{11}-T_{10} \geq d_{1011} & d_{1011}=16 \\
T_{13}-T_{12} \geq d_{1213} & d_{1718}=11 \\
T_{14}-T_{13} \geq d_{1314} & d_{34}=7 \\
T_{15}-T_{14} \geq d_{1415} & d_{78}=10 \\
T_{16}-T_{15} \geq d_{1516} & d_{89}=9 \\
T_{18}-T_{17} \geq d_{1718} & d_{910}=6 \\
T_{19}-T_{18} \geq d_{1819} & d_{1213}=8 \\
T_{20}-T_{19} \geq d_{1920} & d_{1415}=6 \\
T_{21}-T_{20} \geq d_{2021} & d_{1819}=14 \\
T_{2}-T_{1} \geq 0 & \\
T_{12}-T_{1} \geq 0 & T_{i}, T_{j}, d_{i, j}=\text { integer } \\
T_{17}-T_{1} \geq 0 & \\
T_{7}-T_{3} \geq 0 & \\
T_{8}-T_{14} \geq 0 & \\
T_{9}-T_{5} \geq 0 & \\
T_{10}-T_{6} \geq 0 & \\
T_{18}-T_{4} \geq 0 & \\
T_{20}-T_{16} \geq 0 & \\
T_{22}-T_{21} \geq 0 & \\
T_{22}-T_{11} \geq 0 &
\end{array}
$$

\subsection{Results}

The problem that is formulated in section 7.1 is solved by LINDO software. In table 11, optimum duration (crashed time) and budget used for each activity according to cost slop that is shown in table 10 is given. So with budget limitation of $10000 \$$, we can decrease completion time of production. According to budget limitation makespan could be reduced from 60 (before crashing) to 55. 


\begin{tabular}{|c|c|c|}
\hline $\begin{array}{c}\text { Activity } \\
\left(\mathbf{d}_{\text {ij }}\right)\end{array}$ & Crashed Time & Budget Used \\
\hline$d_{23}$ & 7 & 1200 \\
\hline$d_{34}$ & 7 & 0 \\
\hline$d_{45}$ & 8 & 0 \\
\hline$d_{56}$ & 17 & 0 \\
\hline$d_{78}$ & 10 & 0 \\
\hline$d_{89}$ & 9 & 0 \\
\hline$d_{910}$ & 6 & 0 \\
\hline$d_{1011}$ & 16 & 0 \\
\hline$d_{1213}$ & 8 & 0 \\
\hline$d_{1314}$ & 9 & 0 \\
\hline$d_{1415}$ & 6 & 0 \\
\hline$d_{1516}$ & 15 & 5400 \\
\hline$d_{1718}$ & 11 & 0 \\
\hline$d_{1819}$ & 14 & 0 \\
\hline$d_{1920}$ & 9 & 0 \\
\hline$d_{2021}$ & 17 & $\mathbf{9 8 0 0}$ \\
\hline Objective & $\mathbf{5 5}$ & \\
\hline
\end{tabular}

Table 11. The result of the numerical example

By assigning different budgets, different results can be obtained, this is called the sensitivity analysis of the problem. For example, if we assign 2000\$ budget, completion time decrease from 60 to 59, and so. The result can be shown as in table 12 .

\begin{tabular}{|c|c|}
\hline Budget & Makespan \\
\hline 0 & 60 \\
\hline 2000 & 59 \\
\hline 4000 & 58 \\
\hline 5000 & 57 \\
\hline 7000 & 56 \\
\hline 10000 & 55 \\
\hline
\end{tabular}

Table 12. Sensitivity analysis of the numerical example

\section{Conclusions}

This chapter reviewed literature on the flow shop scheduling to determine the optimum completion time(minimum makespan). Flow shop system is involved three subsystems, which are simple flow shop, hybrid flow shop and parallel flow shop. In this chapter discussed about only both simple and hybrid flow shop systems. In simple flow shop we use one machine in each stage with identical process for all jobs, but in hybrid flow shop at least in one stage there is more than one machine for processing. According to the literature review, it was found that we have considered the problem of finding minimum makespan for a given sequence of jobs in both simple and hybrid flow shop by using network approach. As a sequence of jobs on machines is known, the problem can be represented as a critical path network. It is shown that both simple and hybrid flow shop problems can be converted to a network model with regard to predecessor relations and processing time. 
Then it is estimated the cost of crashing time for each activity, which is possible (cost slope). By using a linear programming formulation the critical activities are determined. Assigning some budget to activities that can be crashed by time, causes to reduce the completion time of all the project or makespan, this by itself causes better use of the resources specially machinery and manpower, which by itself increase productivity.

In addition to above, the important subject in this research is ability to sensitivity analysis. So that, by assigning different budgets, it can be obtained different completion time. Thereupon we can select the optimum completion time considering to corresponding budget.

For further research it is suggested to apply linear programming technique to determine makespan subject to budget limitation in some other systems like parallel flow shop.

\section{Acknowledgement}

The author is very grateful to Dr. Hojjati who reviewed this chapter and gave some helpful comments.

\section{References}

Al-Dulaomi, B. \& A.Ali, H. (2008). A Novel Genetic Algorithm Approach for Solving Flow Shop Problem. International Journal of Computer Science and Network Security, Vol. 8, No.9, pp. 229-235.

Brah, S.A. \& Hunsucker, J.H. (1991). Branch and Bound Method for the Flow Shop with Multiple Processors. European Journal of Operational Research, No.51, pp. 88-91.

Campbell, H.G.; Dudeck, R.A. \& Smith, M.L. (1970). A Heuristic Algorithm for the n Job, m Machine Sequencing Problem. Management Science, No.16, pp. 630-637.

French, S. (1982). Sequencing and Scheduling: An Introduction to the Mathematics of the Job Shop. Harwood, Chi Chester.

Gowrishankar, K. (2001). Flow Shop Scheduling Algorithms for Minimizing the Completion Time Variance and the Sum of Squares of Completion Time Deviation from a Common Due Date. European Journal of Operational Research, Vol. 132, pp. 643-665.

Havill, J. \& Mao, W. (2002). On-line Algorithms for hybrid Flow Shop Scheduling.

Hojjati, S.M.H. \& Sahraeyan, A. (2009). Minimizing Makespan Subject to Budget Limitation in Hybrid Flow Shop. Proceedings of International Conference on Computer and Industrial Engineering 39, Troyes, France, July 6-8, 2009.

Khodadadi, A. (2011). Solving Constrained Flow-Shop Scheduling Problem with Three Machines. International Journal of Academic Research, Vol. 3, No. 1, January, 2011, pp. 38-40.

Linn, R. \& Zhang, W. (1999). Hybrid Flow Shop Scheduling: A Survey. Proceedings of International Conference on Computer and Industrial Engineering 37, pp. 57-61.

Pan, J.C.H; Chen, J.S. \& Chao, C.M. (2002). Minimizing Tardiness in a Two-Machine Flow Shop. Computer and Operations Research, Vol. 29, pp. 869-885.

Seda, M. (2007). Mathematical Models of Flow Shop and Job Shop Scheduling Problems. World Academy of Science, Engineering and Technology, pp. 122-127.

Wang, H.; Chow, F. \& Wu, F. (n.d.). A Simulated Annealing for Hybrid Flow Shop Scheduling with Tasks to Minimize Makespan. International Journal of Advanced Manufacturing Technology, Vol.53, No. 5, pp.761-776.

Zijm, W.H.M. \& Nelissen, E. (1990). Scheduling a Flexible Machining Centre. Proceedings of Conference on Engineering Costs and Production Economics 19, pp. 249-258. 


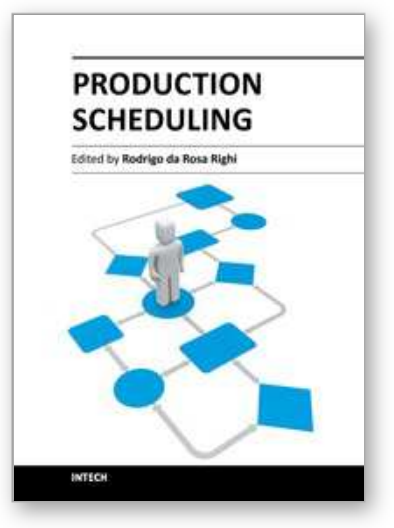

\author{
Production Scheduling \\ Edited by Prof. Rodrigo Righi
}

ISBN 978-953-307-935-6

Hard cover, 242 pages

Publisher InTech

Published online 11, January, 2012

Published in print edition January, 2012

Generally speaking, scheduling is the procedure of mapping a set of tasks or jobs (studied objects) to a set of target resources efficiently. More specifically, as a part of a larger planning and scheduling process, production scheduling is essential for the proper functioning of a manufacturing enterprise. This book presents ten chapters divided into five sections. Section 1 discusses rescheduling strategies, policies, and methods for production scheduling. Section 2 presents two chapters about flow shop scheduling. Section 3 describes heuristic and metaheuristic methods for treating the scheduling problem in an efficient manner. In addition, two test cases are presented in Section 4. The first uses simulation, while the second shows a real implementation of a production scheduling system. Finally, Section 5 presents some modeling strategies for building production scheduling systems. This book will be of interest to those working in the decision-making branches of production, in various operational research areas, as well as computational methods design. People from a diverse background ranging from academia and research to those working in industry, can take advantage of this volume.

\title{
How to reference
}

In order to correctly reference this scholarly work, feel free to copy and paste the following:

Amin Sahraeian (2012). Minimizing Makespan in Flow Shop Scheduling Using a Network Approach, Production Scheduling, Prof. Rodrigo Righi (Ed.), ISBN: 978-953-307-935-6, InTech, Available from: http://www.intechopen.com/books/production-scheduling/minimizing-makespan-in-flow-shop-scheduling-usinga-network-approach

\section{INTECH}

open science | open minds

\section{InTech Europe}

University Campus STeP Ri

Slavka Krautzeka 83/A

51000 Rijeka, Croatia

Phone: +385 (51) 770447

Fax: +385 (51) 686166

www.intechopen.com

\section{InTech China}

Unit 405, Office Block, Hotel Equatorial Shanghai

No.65, Yan An Road (West), Shanghai, 200040, China 中国上海市延安西路65号上海国际贵都大饭店办公楼 405 单元

Phone: $+86-21-62489820$

Fax: $+86-21-62489821$ 
(C) 2012 The Author(s). Licensee IntechOpen. This is an open access article distributed under the terms of the Creative Commons Attribution 3.0 License, which permits unrestricted use, distribution, and reproduction in any medium, provided the original work is properly cited. 